16 Butland RJA, Pang J, Gross ER, Woodcock AA, Geddes DM. Two, six, and 12 minute walking tests in respiratory disease. BMF 1982;284:1607-8.

17 Owens GR, Rogers RM, Pennock BE, Levin D. The diffusing capacity as a predictor of arterial oxygen desaturation during exercise in patients with chronic obstructive pulmonary disease. $N$ Engl $₹$ Med 1984;310 1218-21.

18 Reis AL, Farrow JT, Clausen JL. Pulmonary function tests cannot predict exercise-induced hypoxia in chronic obstructive pulmonary disease. Chest 1988;93:454-9.

19 Cockcroft A, Beaumont A, Adams L, Guz A. Arterial oxygen desaturation during treadmill and bicycle exercise in patients with chronic obstructive airways disease. Clin Sci 1985;68:327-32.

20 Dantzker DR, D'Alonzo GE. The effect of exercise on pulmonary gas exchange in patients with chronic obstructive pulmonary disease. Am Rev Respir Dis 1986; 134:1135-9.

21 Celli BR, Rassulo J, Make B. Dyssynchronous breathing during arm but not leg exercise in patients with chronic airflow obstruction. N Engl ₹ Med 1986;314:1485-90.
22 Martinez FI, Couser JI, Celli BR. Factors inflencing ventilatory muscle recruitment in patients with chronic airflow obstruction. Am Rev Respir Dis 1990;142: 276-82.

23 Peel ET, Anderson G. A dose response study of oxitropium bromide in chronic bronchitis. Thorax 1984 39:453-6.

24 Wilson RC, Jones PW. A comparison of the visual analo scale and modified Borg scale for the measurement of dyspnoea during exercise. Clin Sci 1989;76:277-82.

25 Muza SR, Silverman MT, Gilmore GC, Hellerstein HK, Kelsen SG. Comparison of scales used to quantitate the sense of effort to breathe in patients with COPD. Am Rev Respir Dis 1990;141:909-13.

26 Swinburn CR, Wakefield JM, Jones PW. Relationship between ventilation and breathlessness during exercise in chronic obstructive airways disease is not altered by prevention of hypoxaemia. Clin Sci 1984;67:575-9.

27 Calverley PMA, Leggett RJE, McElderry L, Flenley DC. Cigarette smoking and secondary polycythaemia in hypoxic cor pulmonale. Am Rev Respir Dis 1982;125: 507-10.

\title{
A Research Fellowship at the Brompton: \\ 21 years later
}

Three months into a research fellowship in London in 1972 I took a week off to attend a Cardiothoracic Institute Advanced Medicine Course. At one of the social events a charming gentleman (John Plant), probing my interests and aspirations, detected some dissatisfaction with my research environment. My enthusiastic response to his questioning whether I would like to work at the Brompton prompted an introduction to the "new professor" and his suggestion to her that I might be offered the opportunity to relocate. Three months later I was graciously and warmly welcomed to the Brompton where I embarked on research under the wise and friendly guidance of Tim Clark, Margaret Turner-Warwick and Simon Godfrey, with active support from Mac Cochrane, Ron Logan-Sinclair and others.

Eighteen months at the Brompton with a year generously sponsored by the Board of Governors provided a transforming experience in my career. Building a "Heath Robinson" pressure constant volume plethysmograph for my research projects and running the Brompton's routine lung function laboratory taught me the need for much patience, ingenuity, diplomacy and dogged persistence in the research endeavour itself (and all the related activities associated with its presentation and ultimate publication), and in the "marketing" of a (then sometimes unwanted) lung function service. Meeting, working and socialising with many outstanding and dedicated clinicians/investigators opened my mind to new ways of thinking and a future indelibly stamped by their influence. Other young investigators from South Africa who were subsequently welcomed and similarly graciously supported at the Brompton have returned home to make innovative contributions to respiratory medicine.
The privilege of retaining highly valued friendships with coregistrars who have become prominent in British thoracic medicine, with SHOs who certainly kept one on one's toes and other generous mentors on the consultant staff, played a sustaining role during subsequent decades of work in the difficult, complex and transforming South African environment.

The political arguments for the need to isolate South Africa in the battle against apartheid received widespread support. The lack of any adequate moral basis for the intellectual impoverishment which accompanied the academic boycott led to the concept of selective support as an appropriate means of openly declaring against apartheid and all its abhorrent effects, without succumbing to intimidating and coercive forces implicit in academic boycott inimical to intellectual and professional pursuits

As South Africa lurchingly gropes its way into a better future in which dignity will hopefully be restored to all its citizens, we shall rely heavily on our internal personal resources (contributed to by our constructively critical and yet supportive colleagues) and on intellectual and material support from the industralised world. Tuberculosis, smoking related lung diseases, AIDS, asthma, occupational lung disease, and lung cancer are all major and growing problems in Africa Collaborative, scientific and social research at many levels could offer mutual benefits.

Our dilemmas-a microcosm of issues underlying global instability-represent the opportunity to show that the wide disparities produced by generations of greed, exploitation, and denegration of other cultures can be addressed and reversed through rational, empathetic and peaceful means.

$S$ R BENATAR 